\title{
But what is Leadership? A Systematic Review of the Leadership Concept in View of Heightened Educational Leadership in Africa
}

\author{
Gyaviira Musoke Genza \\ School of Education, College of Education \& External Studies, Makerere University \\ P. O. BOX 7062 Kampala, Uganda \\ Corresponding author: gyaviira.genza@mak.ac.ug
}

\begin{abstract}
Although leadership is one of the most widely researched problems in the social sciences, to-date no standard definition has been developed for it. Most of the more than 650 existing leadership "definitions" have been found to deal with the "how" of leadership, and not the "what" (of leadership) itself, leaving the age-long conceptual confusion surrounding the concept of leadership unresolved. In an attempt to provide a scholarly answer to this problem, the current study leveraged existing literature to provide a refined definition of leadership. More specifically, the study redefined the concept of leadership; highlighted the meaning of leadership in education; and unveiled the concrete implications of the emerging leadership concept. In these endeavours, the study employed an exploratory interpretative systematic review design with a conceptual thematic focus. For conceptual lenses, the study utilized both classical definitional rules and Rost's essentials of leadership, as well as Hallinger's conceptual framework for systematic reviews. In the end, the study generated a more precise definition of leadership, which was particularly applied to education. Implications for heightened educational research and practice in Africa were also unveiled. The study's strongest contribution lies in not only rekindling systematic debate on the meaning of leadership, but also in concretely exemplifying this debate by providing a refined definition of leadership and applying the definition to a given field (education).
\end{abstract}

Keywords: Leadership, Educational leadership, Leadership in Africa, Systematic review.

DOI: $10.7176 / \mathrm{JEP} / 12-9-14$

Publication date:March $31^{\text {st }} 2021$

\section{Introduction}

The role played by leadership in the growth and development of nations in general and institutions in particular cannot be overemphasised (Rosari, 2019; Magara, 2017). Leadership acts as the magnetic glue that does not only bring different forces together, but also keeps them together till mission accomplishment (Mensah, 2019). In education in particular, "the quality of leadership makes a significant difference to school and student outcomes" (Bush, 2008: 1). "But what is leadership?" That is the million dollar question that the current study attempts to answer.

Despite the importance of leadership, its meaning remains contentious, ambiguous, and vague (Oguntibeju et al., 2014). There is no agreed upon definition. Rather, it is estimated that more than 650 documented definitions of leadership exist today (Silva, 2016). Yet most of these definitions deal with "how" leadership is performed, and not with "what" leadership itself is (Walters, 2009). Secondly, "many of those writing about leadership are eager to assert that theirs is the one true definition" (Silva, 2016: 6). How many "one true definitions" do we have then? Due to such "leadership concept clutter" (Ulrich \& Smallwood, c.2012), today many studies use the term leadership anyhow (Karp \& Helgø, 2008), applying it arbitrarily to apparently differing behaviour (Hašková, 2011), for example taking leadership to mean the same thing as management (Day \& Sammons, 2016; Spicker, 2012).

Since clarification of terms is a key mark of scholarship, academic disciplines invest tremendous effort in elaboration of their key concepts and constructs. Definitions help to provide semantic clarity, by clarifying ambiguous terms and, hence, mitigating terminological confusion (Moore, 2009). "Any science or body of knowledge having its subject poorly defined will, by necessity, have the content proportionally disjointed" (Walters, 2009: 37). Consequently, "the lack of a common, objective definition of leadership negates the possibility of common findings or understanding" (Walters, 2009: 35).

Even more practically, however, how can leaders be trained if it is unclear what leadership is? "Millions of dollars are invested by organizations trying to develop their future leaders. But if nobody knows what exactly leadership is, all those efforts could be meaningless" (Silva, 2016: 1). A precise conceptualisation is "the foundation from which leadership can be evaluated, developed and influenced" (Joanna \& Kim, 2011: 8). Thus, defining leadership "is extremely important in order to understand deeply the phenomenon we are studying. Good definitions and clear concepts could enable us to achieve great breakthroughs in the study and practice of leadership" (Pentti, 2003: 74). As Rost (1991) believed, both studying and doing leadership require a clear understanding of the essential nature of leadership. Hence the potential importance of this study in endearing both 
leadership theory and practice, particularly in Africa where quite little of such research exists (Lopez \& Rugano, 2018; Chikoko, Naicker \& Mthiyane, 2015), although Hallinger (2017) speaks of surprising improvements since 2005.

Even then, more than half of the existing African studies on leadership (and management) are from just two countries (S. Africa and Nigeria), with Rwanda and Uganda performing quite poorly in E. Africa (Hallinger, 2017). Yet it is expected that Africa faces unique leadership problems (Lopez \& Rugano, 2018); implying an urgent need for contextualised leadership research that speaks to African experiences of cultural diversity and young populations, for example. In education, Africa can boast of just a few "home-grown insights" (studies) on leadership for school improvement (Chikoko, Naicker \& Mthiyane, 2015). Hallinger (2017) has also indicated that existing literature does not provide much systematic knowledge on how school leaders carry out their roles in Africa. Intensive leadership research and training could be the game changer in revamping entire education systems on the continent (Magara, 2017).

Therefore the purpose of this study is to leverage existing literature to review the leadership concept so as to make leadership research and practice more popular in Africa, particularly in the context of education. The study has three objectives; namely, to redefine the concept of leadership more precisely; to highlight the meaning of leadership in the context of education; and to unveil the implications of the emerging leadership concept.

After a short discussion of the etymological and historical roots of leadership in the next section, the study will examine philosophical roots of definitional science, followed by core methodological underpinnings, and definitional point of departure. Focus then turns to a systematic examination of leadership definitions in PostRostian literature (1991). Finally, the study makes a case for educational leadership, before summing up with study implications, conclusions, and limitations.

\section{Etymological and Historical Considerations}

Etymologically, "leadership" is one of the nouns from the verb "to lead", which originates from the old English word "leden" (or "loedan"), meaning "to make go", "to guide" or "to show the way" (Pentti, 2003). Unlike the noun "leader", which first appeared in the English language as early as the year 1300, "leadership" first appeared about 500 years later (c. 1820) (Pentti, 2003). Thus, Walters (2009) is justified in contending that "in English, the term leadership [sic] has only been used extensively for about 200 years. However, the concept of leading, guiding and influencing can be found as far back as recorded language can be traced" (p. 86). History further reveals that the term "leadership [sic] has been used to refer to a position of predominance as well as...the ability to act with influence while in such a position" (Walters, 2009: 87). However, this double usage problem largely lies beyond the scope of the current study. History further reveals that as disciplines, leadership is older than management, which first got prominence in the first half of the $20^{\text {th }}$ century (Pentti, 2003).

\section{Philosophical roots of definitional science}

Since definitions are meant to state the essence of a thing (Aristotelian principle) (Moore, 2009), the study's linkage to philosophy is expected. More precisely, definitional science is rooted in Philosophy of language, which aims not only at clarity of terms, but also at their logic and objectivity (Ekpenyong \& Ikegbu, 2018). Thus, also "in evaluating and formulating definitions of leadership, logical requirements proper to all definitions are followed" (Walters, 2009: 264). These requirements (or "classical rules") are essentially three; namely, a definition must have a genus and a difference (differentia); its definiens ("meaning part") must be simpler than the definiendum (term being defined); and, its definiens and definiendum must be convertible (Walters, 2009: 158159). The three are propounded by the Classical Theory of Definition (Moore, 2009).

"Genus" is the broad class to which a term belongs; and "differentia" is the distinctive difference. The primary form of a definition is thus that of a genus and a difference, by indicating the whole (broader class) where a term belongs, as well as the subset (specific feature) (Walters, 2009). In the definition of "university" as an educational institution that awards degrees; "educational institution" is the genus (broader class), and "awarding degrees" is the differentia (distinguishing a university from other educational institutions). By definiens (e.g. "degree awarding educational institution") being simpler than "definiendum" (e.g. "university"), what is aimed at is, first, use of positive constructions - "what something is", as contrasted with "what something is not"; hence avoiding negative constructions (Walters, 2009). This principle would be broken by defining "university" as "an educational institution that is neither a primary nor a secondary school".

Secondly, definitional simplicity implies excluding both derivatives (of the definiendum) and circular forms in the definition. Defining university as "a universal educational institution", would be begging the question of what "universal" then means (Moore, 2009). Thirdly, simplicity implies using terms that are less complex than the definiendum (Walters, 2009). Defining a university as "an educational institution that epitomizes epistemological questing" tantamounts to failure in clarifying the term.

On the principle of definiens and definiendum being convertible (Walters, 2009), it means that "If A means B", then "B means A". For example if "a university is an educational institution that awards degrees"; then 
"an educational institution that awards degrees is a university". This principle explains the exclusion of some leadership definitions from the current study, like that by Surji (2015: 154) that "leadership is influence".

Definitional science further indicates that a definition may be connotative (intensional) or denotative (extensional) (Moore, 2009). Being connotative implies defining a term by delineating (outlining) "the set of attributes or defining characteristics shared by that class of objects to which we apply the term" (Moore, 2009: 23 ). This is contrasted with using a denotation, which implies outlining the entire class of objects that share those attributes. The current study believes that defining leadership by simply enumerating the class of all objects that the term refers to would be both deficient and impossible. The study went for a connotative definition; "one in which the phenomenon with which the meaning of the term is connected is broken down into its constituent elements" (Moore, 2009: 7). The advantage of such a definition is that "it not only conveys the meaning of the word but also gives an analysis of the characteristics of the phenomenon itself" (Moore, 2009: 7). Copi and Cohen (2005), as cited by Moore (2009), have even posited that definition by connotation is the most acceptable method of definition in scholarly circles. A connotative definition's definiens states the logically necessary and jointly sufficient conditions for the application of the definiendum, hence sufficiency of definition, as propounded by the Classical Theory of Definition (Walters, 2009; Moore, 2009; Burek, 2004).

Particularly for connotative definitions by genus and differentia, Copi and Cohen (1994) as cited by Walters (2009), gives five more specific rules: Focus on essential features; avoid circularity; capture correct extension (avoid unnecessary stuff); avoid figurative language; and, be affirmative. These five criteria constitute the classical blue print for valid scholarly definitions. The criteria were also considered necessary for a leadership definition because, as Walters (2009) observes, "the multitude of definitions that presently proliferate the field of leadership studies are often presented without acknowledgement of any criteria appropriate to definition, thus allowing for endless attempts to define leadership" (p. 40).

Of the three prominent types of connotative definitions (lexical, stipulative and précising) (Moore, 2009), the study thought its purpose would be better served using a précising definition (also called "précising analytical definition"). A précising definition is one that,

Stipulates additional features [of a term] so as to increase the precision of a term's meaning, thereby eliminating the ambiguities and vagueness characterizing the common usage of the term... It [a précising definition] must remain connected to established usage - one is not free to assign whatever meaning one chooses to the term. However, a précising definition is not a mere report of common usage. It goes beyond lexical definition in that it incorporates additional attributes in the definiens so as to narrow the scope of the term's meaning (Moore, 2009: 4-5).

The current study's précising definition is aimed at spelling out more precisely the meaning of the term "leadership", while at the same time, as much as possible, respecting usage in existing studies. In all, the study aimed at a definition that is both précising and connotative - a précising connotative definition.

\section{Study's core methodology}

The study employed an exploratory interpretative systematic review [SR] design (Hallinger \& Hammad, 2017; Hallinger, 2013; Seers, 2015) with a conceptual thematic focus (Karp \& Helgø, 2008; Ndarukwa, Chimbari \& Sibanda, 2019). SRs (Systematic reviews) methodically bring together research available on a given topic, compare evidence from selected studies, and synthesise it to develop one coherent narrative (Himmelfarb Library, 2020; Seers, 2015). SR research is justified by its potential "role in the advancement of knowledge by highlighting milestones of progress along particular lines of inquiry... [and] laying the groundwork for conceptual analyses and empirical studies" (Hallinger, 2013: 127). "Meaning of leadership" was the current review's thematic focus.

For assembling a sample of studies to be used, the study followed bounded search procedures (Hallinger, 2013), by taking Rost (1991) as the starting point and restricting the sample to leadership studies done thereafter. Since currency was not the study's core preoccupation, the study went as far back as 1991, the year Rost published his seminal work on leadership. The study's time delimitation was thus both historical and pragmatic, basing on Rost (1991) and on availability, respectively. Rationale for Rost (1991) is further discussed below.

The study restricted its searches to the Googlescholar ${ }^{\mathrm{TM}}$ search engine, because it "represents a more suitable database for reviews of Educational Leadership and Management research [sic]" (Hallinger et al., 2017: 5). Use of one search engine is valid as long as the engine indexes a large set of pertinent studies from respected journals (Gumus, Bellibas, Esen \& Gumus, 2018). The key search words used were "meaning of leadership", "concept of leadership", "what is leadership?", and "leadership definition", with the first and second phrases yielding more relevant results.

The study particularly included only those Post-Rostian studies that essentially aimed at defining leadership, hence excluding studies that had only made casual mentions of the meaning of leadership, without a concerted concern for contributing to a bigger understanding of the leadership concept. It is by this criterion that such studies as Kuluchumila (2018) were excluded.

For sample size, SRs have "no magic number that defines the "optimal" number of papers to be included 
[sic]" (Hallinger, 2013: 133). Thus, the study included all and only relevant studies discovered. In the end, the sample consisted of mixed sources (peer-reviewed articles, dissertations, books and book chapters), published in English between 1991 and 2021.

Conceptual lenses were borrowed from the logical criteria of classical definitional science, as well as the four essential elements of Rost (1991)'s prototype leadership definition (discussed below). As much as possible, the study adhered also to Hallinger (2013)'s conceptual framework for conducting SRs in educational leadership and management (p. 130). The framework pivots around stating a study's central topics of interest, conceptual lenses, data sources and types, data analysis techniques, and major results and implications (Hallinger, 2013: 130).

For validity and reliability, Creswell (1998)'s advice that scholars use at least two of his eight checks (as cited by Walters, 2009), was followed. Four checks were utilized: prolonged engagement with the literature (for two years), peer review (two other leadership scholars played the "devil's advocate"), rich description (of diverse leadership conceptualisations), and triangulation of sources (using not only journal articles, but also books and dissertations; even following up sources listed in the references of given Googlescholar ${ }^{\mathrm{TM}}$ studies).

Data analysis involved making sense of each leadership definition using the stated conceptual lenses. Narrative synthesis was then employed to integrate diverse leadership conceptualisations (Hallinger et al., 2017). The review went beyond aggregation of available data to provide further interpretive insights (Ndarukwa et al., 2019) about the meaning of leadership. Data were presented using descriptions, verbatim narratives and tables. Since the study did not involve any access to individual-level data, no ethical approval was deemed necessary (Ndarukwa et al., 2019). Only secondary data already available in the public domain was utilized.

\section{Definitional point of departure}

By design, the early 1990s were the study's starting point. The reason was that, in as far as leadership conceptualisation is concerned, this was the time of publication of "two milestone leadership works" (Walters, 2009: 13): Bass (1990) and Rost (1991). Bernard Morris Bass (1925-2007) examined 7,500 leadership studies to come up with a 1990 leadership concept contained in a book entitled, "Bass and Stodgill's Handbook of Leadership: Theory, Research, and Managerial Applications". At about the same time, Joseph C. Rost (1931-2008) assessed 450 books, chapters and/or articles to come up with a book entitled "Leadership for the Twenty-First Century". Here, Rost examined definitions of leadership from 1900 to1979. The importance of these two seminal works is evidenced by Walters (2009);

In the nearly 20 intervening years [1990-2010], since Rost and Bass, there was no further evidence in the literature that anyone had again tried to combine or summarize various leadership definitions into a single definition, or to identify common elements in any context (p. 19).

The current study also sought to discover existing leadership "commonalities" and "convergences", and to build on these to further an appreciation of the leadership concept.

Bass (1990) defined leadership as: An interaction between two or more members of a group that often involves a structuring or restructuring of the situation and the perceptions and expectations of the members (pp. 19-20). The current study found this definition to be disjointed and lacking in precision. More so, its definiens is not simpler than the definiendum. Thus, the current study opted for Rost (1991) as the point of departure.

Rost (1991) defined leadership as: "an influence relationship among leaders and followers who intend real changes that reflect their mutual purposes" (p. 102). He also outlined the essential elements of his definition: (1) Influence relationship; (2) leaders and followers as the people in the relationship; (3) intending of real changes; and (4) development of mutual purposes. The four are further explained.

According to Rost (1991: 105-106), leadership is not a position but a relationship based on influence (not statutory authority). This "influence" is multi-dimensional (top-down, down-up, and horizontal). Thus, anyone can be a leader or a follower, depending on who is influencing the other. Secondly, the people involved in the relationship are leaders and followers (Rost, 1991: 107-112), not superordinates and subordinates. For Rost, followers also carry out leadership, not followership. Typically there is more than one follower and more than one leader in the relationship, hence the plural element in the definition.

Thirdly, leaders and followers intend real changes (pp. 113-117). Intention means "willingness" or "purposeful desire". For Rost, changes (plural) can only be championed now (in the present); otherwise their realisation cannot be in the now. In the present, leaders and followers can only give solid evidence of this intention (by their words and actions). By "real" changes is meant developments that are substantial (not cosmetic); those transforming the holistic aspirations of both parties. Lastly, leaders and followers develop mutual "purposes", not (mere) "goals" (Rost, 1991: 118-123). Like vision, purpose is holistic. The mutuality ("fellowship") of purposes is forged in the non-coercive influence relationship.

Rost (1991)'s leadership definition is itself not without issues, otherwise it would perhaps already have settled leadership definition controversies. For example, one sees that Rost (1991)'s definition is tautological (circular), by defining "leadership" in terms of "leaders and followers". Secondly, does any kind of influence do? What unique kind of influence is involved in leadership, as contrasted, for example, with another kind in 
management? Further critique and correction of Rost (1991)'s definition was deemed necessary, using connotative definitions discovered in Post-Rostian literature.

\section{Post-Rostian leadership conceptualisations}

A review of leadership definitions that were developed after Rost's was guided by the following questions: How evident are Rost's four essential elements in post-Rostian literature? Does the literature perhaps ignore them and come up with its own other elements? Might the essential elements end up being more than Rost's four? Does the literature perhaps reduce the elements to less than four? Looking for Rost in studies that came after him is an attempt at gauging both the validity and currency of Rost's leadership definition, and of searching for ways of improving upon it. The current study capitalized on definitions that met the general logical requirements (Walters, 2009). The discovered definitions are presented verbatim; however, some few were adapted, for example Winston and Patterson (2006)'s, because it was defining "leader", yet the current study defines "leadership". But for all definitions (verbatim or not) source pages are indicated - for readers' further corroboration.

Table 1: Chronological presentation of pertinent post-Rostian leadership definitions

\begin{tabular}{|c|c|c|c|}
\hline & Source study & Leadership definition & Essential elements \\
\hline 1. & $\begin{array}{l}\text { Patterson (1993) in } \\
\text { Murphy, Goldring, } \\
\text { Cravens, Elliot \& } \\
\text { Porter (2007: 2) }\end{array}$ & $\begin{array}{l}\text { "The process of influencing others to achieve mutually agreed upon } \\
\text { purposes for the organization" }\end{array}$ & $\begin{array}{ll}\text { - } & \text { Present: } 1,2,4 \\
\text { - } & \text { Absent: } 3 \\
\text { - } & \text { New (element): Organisational } \\
& \text { setting. }\end{array}$ \\
\hline & $\begin{array}{l}\text { Barker (1997: } 351) \\
\text { summarized Rost's } \\
\text { definition as: }\end{array}$ & $\begin{array}{l}\text { "A dynamic social and political relationship that is based in a mutual } \\
\text { development of purposes which may never be realized" }\end{array}$ & $\begin{array}{ll}- & \text { Present: } 1,4 \\
\text { - } & \text { Absent: } 2,3 \\
\text { - } & \text { New: None (seen) }\end{array}$ \\
\hline & $\begin{array}{l}\text { Koontz \& Weihrich } \\
(1998: 344)\end{array}$ & $\begin{array}{l}\text { "The art or process of influencing people so that they will strive } \\
\text { willingly and enthusiastically toward the achievement of group goals" }\end{array}$ & $\begin{array}{ll}\text { - } & \text { Present: } 1,2,4 \\
\text { - } & \text { Absent: } 3 \\
\text { - } & \text { New: None (seen) }\end{array}$ \\
\hline 4. & Musaazi (2000) & $\begin{array}{l}\text { A social process of influencing the behaviour and activities of an } \\
\text { organisation or groups to achieve the organizational goals. }\end{array}$ & $\begin{array}{ll}\text { - } & \text { Present: } 1,2 \\
\text { - } & \text { Absent: } 3,4 \\
\text { - } & \text { New: Organizational setting }\end{array}$ \\
\hline 5. & Cacioppe (2001: 9) & $\begin{array}{l}\text { "The ability to influence and develop individuals, teams and } \\
\text { organisations to achieve a worthwhile vision that meets the present } \\
\text { needs of everyone and everything affected by their work". }\end{array}$ & $\begin{array}{ll}\text { - } & \text { Present: } 1,2,3,4 \\
\text { - } & \text { Absent: None } \\
\text { - } & \text { New: Developing individuals } \\
& \text { \& groups }\end{array}$ \\
\hline & $\begin{array}{l}\text { Fairholm, } \quad(2002: \\
\text { 34) }\end{array}$ & "The art of influencing people to accomplish organizational goals". & $\begin{array}{ll}\text { - } & \text { Present: } 1,2 \\
\text { - } & \text { Absent: } 3,4 \\
\text { - } & \text { New: Organisational goals }\end{array}$ \\
\hline & $\begin{array}{l}\text { Yukl, }(2002: 7) \& \\
\text { Yukl }(2006: \quad 8) \\
\text { [Definition } \\
\text { remained the same - } \\
\text { verbatim] }\end{array}$ & $\begin{array}{l}\text { "A process of influencing others to understand and agree about what } \\
\text { needs to be done and how to do it, and the process of facilitating } \\
\text { individual and collective efforts to accomplish shared objectives" }\end{array}$ & $\begin{array}{ll}\text { - } & \text { Present: } 1,2,4 \\
\text { - } & \text { Absent: } 3 \\
\text { - } & \text { New: None (seen) }\end{array}$ \\
\hline & $\begin{array}{l}\text { Bush \& Glover } \\
(2003: 10)\end{array}$ & $\begin{array}{l}\text { "A process of influence leading to the achievement of desired } \\
\text { purposes. It involves inspiring and supporting others towards the } \\
\text { achievement of a vision for the school which is based on clear personal } \\
\text { and professional values". }\end{array}$ & $\begin{array}{ll}\text { - } & \text { Present: } 1,2,4 \\
\text { - } & \text { Absent: } 3 \\
\text { - } & \text { New: organisational vision }\end{array}$ \\
\hline 9. & $\begin{array}{l}\text { Antonakis, } \\
\text { Cianciolo \& } \\
\text { Sternberg (2004: 5) }\end{array}$ & $\begin{array}{l}\text { "The influencing process - and its resultant outcomes - that occurs } \\
\text { between a leader and followers and how this influencing process is } \\
\text { explained by the leader's dispositional characteristics and behaviors, } \\
\text { follower perceptions and attributions of the leader, and the context in } \\
\text { which the influencing process occurs". }\end{array}$ & $\begin{array}{ll}\text { - } & \text { Present: } 1,2 \\
\text { - } & \text { Absent: } 3,4 \\
\text { - } & \text { New: Leader \& follower } \\
& \text { attributes; context (time \& } \\
\text { space). }\end{array}$ \\
\hline & $\begin{array}{l}\text { Winston } \quad \& \\
\text { Patterson (2006: 7) }\end{array}$ & $\begin{array}{l}\text { Leadership is the process - by one or more people - of selecting, } \\
\text { equipping, training, and influencing one or more follower(s) who have } \\
\text { diverse gifts, abilities and skills, and focusing the follower(s) to the } \\
\text { organization's mission and objectives causing the follower(s) to } \\
\text { willingly and enthusiastically expend spiritual, emotional, and } \\
\text { physical energy in a concerted coordinated effort to achieve the } \\
\text { organizational mission and objectives. }\end{array}$ & $\begin{array}{ll}\text { - } & \text { Present: } 1,2 \\
\text { - } & \text { Absent: } 3,4 \\
\text { - } & \text { New: Organisational setting. }\end{array}$ \\
\hline & $\begin{array}{l}\text { Vroom \& Jago } \\
(2007: 18)\end{array}$ & $\begin{array}{l}\text { "A process of motivating people to work together collaboratively to } \\
\text { accomplish great things" }\end{array}$ & $\begin{array}{ll}\text { - } & \text { Present: } 1,2,3 \\
\text { - } & \text { Absent: } 2,4 \\
\text { - } & \text { New: None (seen) }\end{array}$ \\
\hline & $\begin{array}{l}\text { OECD-ISL as cited } \\
\text { by Révész (2011) }\end{array}$ & $\begin{array}{l}\text { The process of intentional influence exerted by one person (or group) } \\
\text { over another/others to inspire the activities and relationships in an }\end{array}$ & $\begin{array}{ll}\text { - } & \text { Present: } 1,2 \\
\text { - } & \text { Absent: } 3,4\end{array}$ \\
\hline
\end{tabular}


organization. Achieving organisational goals is the essence of such intentional influence.

13. Northouse (2013) in (Magara, 2017: 151)

14. Smith (2013: 2) (2013: 310)

16. Kruse (2013: 3$)$

17. Starr (2014) in Mayra (2016: 36)

in

18. Silva (2016: 3$)$
"Motivating, influencing and facilitating change, while gaining support and supporting followers through trust and inspiration"

"A process whereby an individual influences others to achieve a common goal and is composed of leaders, followers, and situations".

"The ability to adapt the given settings, so that everyone feels empowered to contribute creatively, to solving the problems in a given situation"

"Leadership is a process by which a person influences others to accomplish an objective and directs the organization in a way that makes it more cohesive and coherent".

"Leadership is a process of social influence, which maximizes the efforts of others, towards the achievement of a goal".

"The process of interactive influence that occurs when, in a given context, some people accept someone as their leader to achieve common goals".
New: Group leadership;

organisational setting.

Present: 1, 2, 4

Absent: 3

New: Situational dynamics.

Present: 2

Absent: 1, 3, 4

New: Problem solving; given situations.

Present: 1,2

Absent: 3,4

New: Group cohesion; organisational setting.

Present: 1,2, 4

Absent: 3

New: None (seen)

Present: 1, 2, 3

Absent: 4

New: Trust

Present: 1, 2, 4

Absent: 3

New: Contextual realities.

Table 1 reveals that Rost's essential elements have been variously represented by Post-Rostian literature. The first element ("influence relationship") is directly reflected in such phrases as "the process of influencing others" (Murphy et al., 2007), "a dynamic social and political relationship" (Barker, 1997), and "process of interactive influence" (Silva, 2016). In other studies, however, an "influence relationship" is only implied, as in "process of motivating people" (Vroom et al., 2007), whereby motivation is taken to be a form of influence (Vroom et al., 2007). Nearly all current definitions of leadership involve the process of influence (Walters, 2009). Thus, the first essential element is found to hold much currency in Post-Rostian literature.

For "leaders and followers" ( $2^{\text {nd }}$ element), it is directly visible in such phrases as "influence exerted by one person (or group) over another/others" (Révész, 2011)), and "a person influences others" (Sharma et al., 2013). Indirectly, it is implied by "influencing people" (Fairholm, 2002) or "influencing others" (Yukl (2006), since two groups (or more) are implied. For the third element ("real changes"), the study saw it directly in "facilitating change" (Mayra, 2016); but only implied in "to achieve a worthwhile vision" (Cacioppe, 2001), and "to accomplish great things" (Vroom et al., 2007). Lastly, "mutual purposes" were more directly perceptible in "a mutual development of purposes" (Barker, 1997), "mutually agreed upon purposes" (Murphy et al., 2007), and "achievement of desired purposes" (Bush et al., 2003). Indirectly, it was read in expressions such as "organizational mission and objectives" (Winston et al., 2006), and "achievement of group goals" (Koontz et al., 1998). To get a more precise status of Rost in Post-Rostian studies, a condensed representation of each of the above four elements was summarized as in Table 2 .

Table 2: Condensed representation of each essential element in Post-Rostian studies

\begin{tabular}{llccc}
\hline & \multicolumn{2}{c}{ Rostian essential element } & Studies in which it is present & \multicolumn{2}{c}{ Statistically } \\
\hline & & & $\mathbf{f}(\mathbf{n}=\mathbf{1 8})$ & $\mathbf{\%}$ \\
\hline 1. & Influence relationship & $1,2,3,4,5,6,7,8,9,10$, & & $\mathbf{9 4}$ \\
& & $11,12,13,15,16,17,18$ & 17 & \\
\hline 2. & Leaders and followers & $1,3,4,5,6,7,8,9,10,11$, & & $\mathbf{9 4}$ \\
\hline & & $12,13,14,15,16,17,18$ & 3 & $\mathbf{1 7}$ \\
\hline 3. & Intention of real changes & $5,11,17$ & 9 & $\mathbf{5 0}$ \\
\hline 4. & Development of mutual purposes & $1,2,3,5,7,8,13,16,18$ & 9
\end{tabular}

Table 2 reveals that Post-Rostian literature overwhelmingly confirms Rost (1991)'s first and second essential elements by $94 \%$. The same literature is found to have rejected Rost's element of "real changes", since only $17 \%$ of the studies reflect it. The fourth element was confirmed and rejected in equal measure (50\% by $50 \%)$. However, further analysis of Rost (1991) reveals that his "mutual purposes" and "real changes" are quite similar - purpose/vision is the desired change. Thus, a leadership definition that in essence has "mutual purposes", such as Silva (2016), does not really need to mention "real changes"; it would be a redundancy. Perhaps that is why, according to Table 2, of the nine (9) studies that have either "mutual purposes" or "real changes" (50\%), only one study (Cacioppe, 2001) goes ahead to include the other. Said differently, only one study has both "mutual purposes" 
and "real changes" in its definition.

The researcher interpreted these findings to mean that Rost (1991)'s essential elements are actually three, not four. Secondly, since it is the same "real changes" element that had least frequency in Post-Rostian studies (17\%), we could as well do away with it as the first correction to Rost (1991). Thus, provisionally, Rost (1991)'s definition reduces to: An influence relationship among leaders and followers who strive after mutual purposes.

An analysis of data in Table 1 yielded also some two "new" elements that Rost (1991) did not include in his definition, yet five to six Post-Rostian studies have them. The two are "organisational/group setting" and "contextual dynamics", as in Table 3.

Table 3: New "essential" elements

\begin{tabular}{|c|c|c|c|c|}
\hline & \multirow[t]{2}{*}{ New element } & \multirow[t]{2}{*}{ Studies with the element } & \multicolumn{2}{|c|}{ Statistically } \\
\hline & & & $f(n=18)$ & $\%$ \\
\hline 1. & Organisational/group setting & $4,6,8,10,12,15$ & 6 & 33 \\
\hline 2. & Contextual dynamics & $1,9,13,14,18$ & 5 & 28 \\
\hline
\end{tabular}

Table 3 indicates that whereas six studies (33\%) included an element of "organisational / group setting" in their leadership definitions; five studies (28\%) depicted a "contextual dynamics" element. How "essential" are these elements in the definition of leadership? For example, must leadership necessarily be conceptualised in terms of an organisational context? What is the role of situational factors such as time and space in the eventual play out of the leader-follower game? Further literature review was done to gather "data" on these issues.

The review indicated that truly leadership takes place in the context of a group (Meraku, 2017), team (Hogan \& Kaiser, 2005) or organisation (such as school) (Ogawa \& Bossert, 2000), and is meant to influence the attainment of organisational goals (Meraku, 2017; Ogawa et al., 2000). However, the literature was quiet on whether, the term "organisation" is necessary in a leadership definition. The study that came close to affirm the inclusion of "group" was Hogan et al. (2005), which contended that "leadership should be defined in terms of the ability to build and maintain a group that performs well" (p. 172). Nevertheless, in general it did not look necessary to include the word "group" (or "organisation") in the definition.

For "situation" - in tandem with contingency theories (Oc, 2018; Vroom et al., 2007) - literature revealed that leader-follower relations take place in the interplay of given contexts (Antonakis, Avoliob \& Sivasubramaniamc, 2003). Thus, contextual factors are key facilitators or obstacles of leadership enactment (Brauckmann, Pashiardis \& Ärlestig, 2020). Similarly, for Vroom et al. (2007), situations do not only shape how leaders behave, but also affect the consequences of leaders' behaviour. Thus, Oc (2018) and Jepson (2009) rejoice that leadership research has, at least recently, woken up to the importance of contextual variables in leadership practice. These are variables such as the immediate social context, cultural context, and institutional context (Jepson, 2009). Some of these are internal (within an organisation); others are external (Alexander, Anderson, Anterasian \& Lee, 2017; Braun, Schyns \& Peus, 2016; Antonakis et al., 2003). If leadership is affected by such critical contextual factors, depicting them in a leadership definition appeared to be logical. The study therefore makes another correction to Rost and defines leadership as: An influence relationship among different persons who agree to work together in a given situation so as to realise their mutual purposes.

However, there was still need of qualifying "influence", since not any kind of "influence" (relationship) is leadership. Some helpful qualifying hints were spotted in Post-Rostian studies: "intentional influence" (Révész, 2011); "social influence" (Kruse, 2013); "legitimate interaction" (James, Connolly \& Hawkins, 2019); and "interactive influence" (Silva, 2016). The last one was found preferable because it implies dynamism (passion), collaboration (teamwork) and collegiality (among equals). Thus, the study's refined leadership definition is: $A n$ interactive influence relationship among different persons who agree to work together in a given situation so as to realise their mutual purposes.

This definition seems to meet the three general logical requirements (Walters, 2009). It has both a genus and a difference. Its genus is "leadership as a relationship". Its difference is "influence among different persons who agree to..." Secondly, the definition's definiens is simpler than the complex term "leadership". Thirdly, the definiens and definiendum are convertible. Without losing sense, we may say: "An influence relationship among different persons who agree to work together in a given situation in order to realise their mutual purposes is leadership".

Lastly, the refined definition satisfies also Copi et al. (1994)'s five more specific definitional rules (in Walters, 2009). First, only essential features have been included in the definition. These are: influence relationship; different persons (being involved); working together to realise mutual purposes; and (doing so within) the context of a given situation. Second, as a correction for Rost (1991)'s circularity, the words "leaders and followers" have been dropped. Thirdly, it looks like the resultant definition is parsimonious (economical); only necessary concepts 
have been included. Also figurative language has been avoided ( $4^{\text {th }}$ rule); and the definition is affirmative (what leadership is), not negative ( $5^{\text {th }}$ rule). The definition will now be applied to education - one of the disciplines in which leadership is most studied (Spicker, 2012).

\section{Leadership in education contexts}

Using the refined definition of leadership in general, how are we to define leadership in education in particular? This was the study's second objective. In education, leadership is usually referred to as "educational leadership" [EL], or simply "school leadership" [SL] (Dalal \& Rani, 2013). Although many studies use the terms EL and SL synonymously (Waite \& Bogotch, 2017; Leithwood et al., 2006), the current study preferred EL because SL appears to be a subset of EL. Secondly, SL is quite close to education management; for example in the United Kingdom, "SL" has supplanted "educational management" (Day \& Sammons, 2016). However, the current study utilized also some studies that used SL, as long as they applied SL in terms of influence behaviour. Literature reviewed yielded a few but informative connotative definitions of EL (Table 5).

Table 5: Sample connotative definitions of educational leadership

Source Definition

Researcher's comments

$\begin{array}{lll}\text { 1. James, Connolly } & \& & \text { EL as "legitimate interaction in an educational } \\ \text { Hawkins (2019: 618) } & \begin{array}{l}\text { institution intended to enhance engagement with } \\ \text { the institutional primary task [of teaching \& } \\ \text { learning]" }\end{array}\end{array}$

\section{Dalal \& Rani (2013: 1)}

"Leadership in school is the process of enlisting and guiding the talents and energies of teachers, pupils and parents towards achieving common educational aims".

\section{EPNoSL [European Policy Network of School Leadership] as cited by Kollias (2013: 13)}

\begin{abstract}
SL as "a multi-faceted process of strategically using the unique skills and knowledge of teachers, pupils, and parents, toward achieving common educational goals. It is more about relationships rather than people or processes... Leadership is present at all levels of an organization, directed at serving the most important stakeholders, through inspiring others in the organization to take part in the management process... School leadership therefore coveys dynamism and pro-activity and is not restricted to principals or school heads but also includes other leaders in education, such as members of a formal leadership team and other persons who contribute towards the aims of the school, even including student leadership"
\end{abstract}

Process: Legitimate interaction (authentic interface).

- Participants: Those in educational institutions.

- $\quad$ Bottom line: Enhancing teaching \& learning.

- Process: Enlisting \& guiding.

- Participants: Staff, learners \& even parents.

- Bottom line: Achievement of educational aims.

Process: Purposeful use of others' resources; inspiring others.

- Participants: school heads, leadership teams, teachers, pupils, and parents (all levels).

- Bottom line: Achieving common education goals (in general), not just classroom instruction only.

According to Table 5, EL is about "legitimate interaction" (James et al., 2019), "enlisting and guiding others" (Dalal et al., 2013), "strategic use of others' resources" (EPNoSL, in Kollias, 2013), and/or "value-based influence" (Bush, 2008). Participants in it are school heads, teachers, teams, learners, and even parents (EPNoSL, in Kollias, 2013); and is aimed at achieving common education goals (in general) (Dalal et al., 2013; Kollias, 2013; Bush, 2008), but particularly enhancing teaching and learning (as the bottom line) (James et al., 2019).

The current study assumed the above constructs into its refined definition of leadership. The definition's element of "interactive influence relationship" catered for James et al. (2019)'s "legitimate interaction" and sister notions such as "value-based influence" (Bush, 2008). "Participants" were discovered in "among different persons", which became "among school heads, teachers, teams, learners, and even parents". But this seemed to be a long yet far from exhaustive list of members. It was reduced to "among different stakeholders". Lastly, for bottom 
line, the study adapted "common education goals, particularly teaching and learning" as the "mutual purposes". The current study therefore defines EL as "an interactive influence relationship among different stakeholders who agree to work together in a given situation so as to realise their mutual purposes in general, but enhancing teaching and learning in particular".

\section{Study implications for research and practice}

First, leadership being an interactive influence relationship or behaviour, and not an office, anyone in an organisation can, and should, play the leader. For example, one does not need to first be appointed a head teacher, to begin leading. Even those at the bottom of organisational hierarchies (e.g. classroom teachers) can exercise leadership. The often heard excuse by many teachers in Africa for not making significant differences in their institutions - that they are "mere" teachers - is unwarranted. Leadership knows no hierarchical levels. Anyone can turn into a leader, for example by ensuring subject mastery and professional expertise, and influencing colleagues to transform learning in their school or district. This is teacher leadership, which is badly needed in Africa today. We teachers have no right to be "mere teachers" anymore; ours is the right to be leaders at the same time. Since formal positions are few in schools (vis-à-vis the number of teachers), most of us will be non-positional leaders, who, however, wield massive influence in bringing about change and development on the continent.

Similarly, the study's findings imply that those appointed organisational managers or school administrators are not necessarily the de facto leaders in their institutions. Although ideally leadership and management should be visible in the same person such as head teacher, the reality is often different. Many heads stop at "heading"; they fail to metamorphose into leaders, and therefore remain "mere" administrators or "mere" managers. Whereas management is acquired from above - "by virtue of this appointment" - leadership is acquired from "below" (by one's words and actions). Once a head teacher eventually succeeds in winning over the minds and hearts of students, staff and other stakeholders, then s/he is exercising leadership. The implication is that whether head or classroom teacher, each one has some journey (of personal transformation and influence) to walk before becoming a leader.

Another implication is that though leadership is different from management, the two are needed in the successful functioning of organisations such as schools. Every new educational program needs to be both led and managed. For example, an inspiring school curriculum introduced by a school board does not only require trustable individuals (leaders) to convince teachers' hearts and minds to buy into it, but also skilled planners and organisers (managers) to execute it efficiently and effectively. In order for the "organisational coin" to be complete, we need both sides (leadership and management) to be present. How exactly a multiplicity of active leaders and administrators can co-exist, in a school setting for example, is an issue that deserves more scholarly attention, particularly in Africa where head teachers often play the boss (Bush, 2008) - the only bull in the kraal.

\section{Conclusion}

The study concludes that although the issue of a leadership definition constitutes an age-old problem in leadership research, existing literature is not without plausible answers, only waiting to be assembled into a meaningful whole. Secondly, the study contends that leadership is "an interactive influence relationship among different persons who agree to work together in a given situation so as to realise their mutual purposes". This technical/strict definition differentiates leadership from management. However, both are needed for organisational excellence. For EL (Educational Leadership), the study has redefined it as "an interactive influence relationship among different stakeholders who agree to work together in a given situation so as to realise their mutual purposes in general, but enhancing teaching and learning in particular". These conceptualisations (of both leadership and EL) will help to heighten educational leadership research and practice in Africa.

\section{Contribution}

The study's strongest contribution lies in not only rekindling systematic debate on the meaning of leadership, but also in concretely exemplifying such debate. Notably, this study has carried out debate by building on "answers" already existing in literature, and not simply by introducing entirely new ideas from nowhere, as many previous studies had done. Secondly, the study unveils and popularizes a relatively novel approach to conceptual clarifications in leadership studies, education and beyond, grounded on the logical principles of definitional science. In this regard, the study exemplifies both how to state a précising connotative definition and how to measure the strength of the ensuing conceptualisation by using definitional science principles. Finally, the study clearly brings out the possibility and desirability of becoming outstanding leaders even without first occupying any formal position. This study's revelations will hopefully encourage more individuals to dare mutate into exceptional leaders.

\section{Limitations}

The current study's restriction to secondary data limits it. An empirical testing of the refined definition's 
validity remains desirable. Secondly, since leadership is often confused with management, a concurrent discussion of the relationship between leadership and management would be useful. The study has also raised storm on the question of how a multiplicity of active leaders and administrators can mutually co-exist in the same institution. However, these issues lay beyond the scope of the current study. Future research should take interest in such issues.

\section{References}

Alexander, W., Anderson, M., Anterasian, C. and Lee, J. (2017). Context matters: The five elements of context that most impact senior leader success. US: SpencerStuart.

Almaki, S. H., Silong, A. D., Idris, K. and Wahat, N. W. A. (2016). Understanding of the Meaning of Leadership from the Perspective of Muslim Women Academic Leaders. Journal of Educational and Social Research. Vol. 6 No.2; pp. 225-236.

Antonakis, J. Avoliob, B. J. and Sivasubramaniamc, N. (2003). Context and leadership: an examination of the nine-factor full-range leadership theory using the Multifactor Leadership Questionnaire. The Leadership Quarterly, 14 (3), pp. 261-295.

Antonakis, J., Cianciolo, A. T., Sternberg, R. J. (2004). Leadership: past, present, and future. The nature of leadership. Los Angeles: SAGE.

Barker, R.A. (1997). How Can We Train Leaders if We Do Not Know What Leadership Is? Human Relations, Vol. 50, No. 4, 1997, pp. 343-362.

Bass, B. M. (1990). Bass \& Stodgill's Handbook of Leadership: Theory, Research, and Managerial Applications ( $3^{\text {rd }}$ Ed.). New York: The Free Press.

Brauckmann, S., Pashiardis, P., Ärlestig, H. (2020). Bringing context and educational leadership together: fostering the professional development of school principals. Professional Development in Education. https://doi.org/10.1080/19415257.2020.1747105.

Braun, S., Schyns, B. and Peus, C. (2016). Conclusion: leadership lessons from compelling contexts. Monographs in leadership and management, 8 (8), pp. 465-479.

Bush, T. (2008). Leadership and management development in education. Los Angeles: SAGE.

Bush, T. and Glover, D. (2003). School leadership: concepts and evidence. University of Reading: NCSL.

Cacioppe, R. (2001). Redefining leadership for the 21st century. University of Western Australia: Integral Leadership Centre.

Burek, P. (2004). Adoption of the Classical Theory of Definition to ontology modeling. https://www.researchgate.net/publication/221655979

Chikoko, V., Naicker, I. and Mthiyane, S. (2015). School leadership practices that work in areas of multiple deprivation in South Africa. Educational Management Administration \& Leadership, Vol. 43(3), pp. 452467.

Day, C. and Sammons, P. (2016). Successful school leadership. Berkshire: Education Development Trust.

Ekpenyong, B. \& Ikegbu, E. A. (2018). The language of philosophy and the philosophy of language: a symbiotic paradigm. Budapest International Research and Critics Institute-Journal (BIRCI-Journal). Volume I, No 3, pp. 296-305. www.birci-journal.com

Fairholm, M. R. (2002). Defining leadership: a review of past, present, and future ideas. Center for Excellence in Municipal Management: George Washington University.

Gumus, S., Bellibas, M. S., Esen, M. \& Gumus, E. (2018). A systematic review of studies on leadership models in educational research from 1980 to 2014. Educational Management Administration \& Leadership, Vol. 46(1) 25-48

Hallinger, P. (2013). A conceptual framework for systematic reviews of research in educational leadership and management. Journal of Educational Administration, 51; 126-149.

Hallinger, P. \& Hammad, W. (2017). Knowledge production on educational leadership and management in Arab societies: A systematic review of research. Educational Management Administration \& Leadership; pp. $1-$ 17. DOI: $10.1177 / 1741143217717280$

Hallinger, P. (2017). Surfacing a hidden literature: A systematic review of research on educational leadership and management in Africa. Educational Management Administration \& Leadership, 20(10), pp. 1-23.

Hogan, R. and Kaiser, R. B. (2005). What we know about leadership. Review of General Psychology, Vol. 9, No. 2, pp. 169-180.

Himmelfarb Library, 2020). Meta-Analysis. https:/himmelfarb.gwu.edu/tutorials/study design $101 /$ metaanalyses.cfm

James, C., Connolly, M. \& Hawkins, M. (2019). Reconceptualising and redefining educational leadership practice, International Journal of Leadership in Education. DOI: 10.1080/13603124.2019.1591520

Joanna, P. \& Kim, T. J. (2011). Leadership development: crisis, opportunities and the leadership concept. Leadership, Volume 7, Number 2, pp. 137-150.

Karp, T. \& Helgø, T. (2008). The future of leadership: the art of leading people in a "post-managerial" 
environment. Foresight; Vol. 10 No. 2 (2008), pp. 30-37.

Koontz, H. \& Weihrich, H. (1998). Essentials of management (5th Ed.). New Delhi: Tata McGraw-Hill Publishing Company Ltd.

Kruse, K. (2013) What Is Leadership? Forbes. http://www.forbes.com/sites/kevinkruse/ 2013/04/09/what-is-leadership/2/

Kuluchumila, R. C. (2018). Researching education leadership in Tanzanian secondary schools. Mauritius: LAP Lambert Academic Publishing.

Law, S. \& Glover, D. (2011). Educational leadership and learning: practice, policy and research. Buckingham: Open University Press.

Leithwood, K., Day, C., Sammons, P., Harris, A. and Hopkins, D. (2006). Successful School Leadership: What It Is and How It Influences Pupil Learning. NCSL; University of Nottingham.

Lopez, A. E. and Rugano, P. (2018). Educational leadership in post-colonial contexts: What can we learn from the experiences of three female principals in Kenyan secondary schools? Education Sciences Journal, 8 (99), pp. 1-15.

Mensah, J. (2019) Sustainable development: Meaning, history, principles, pillars, and implications for human action: Literature review. Cogent Social Sciences, 5(1), pp. 1-21.

Meraku (2017). Role of leadership in organisational effectiveness. Journal of Economics, Business and Management, Vol. 5, No. 11, pp. 336-340.

Moore, J. W. (2009). The Logic of Definition. DRDC, Toronto.

Ndarukwa, P., Chimbari, M. J. \& Sibanda, E. N. (2019). Protocol on a systematic review of qualitative studies on asthma treatment challenges experienced in Sub-Saharan Africa. Systematic Review 8, 149 (2019). https://doi.org/10.1186/s13643-019-1068-7

Oc, B. (2018). Contextual leadership: A systematic review of how contextual factors shape leadership and its outcomes. The Leadership Quarterly, Vol. 29, Issue 1, pp. 218-235. https://doi.org/10.1016/j.leaqua.2017.12.004

Ogawa, R. T. and Bossert, S. T. (2000). Leadership as an organisational quality. The Jossey-Bass education series. San Francisco: Jossey-Bass Inc., pp. 38-58.

Patterson, J. L. (1993). Leadership for Tomorrow's Schools. Alexandria, VA: Associaiton for Supervision and Curriculum Development.

Rosari, R. (2019). Leadership definitions application for lecturers' leadership development. Journal of Leadership in Organizations, Vol.1, No. 1 (2019), pp. 17-28.

Rost, J. C. (1991). Leadership for the twenty-first century. New York: Praeger.

Seers, K. (2015). Qualitative systematic reviews: their importance for our understanding of research relevant to pain. British Journal of Pain, Vol. 9(1), 36-40.

Sharma, M. K. and Jain, S. (2013). Leadership management: principles, models and theories. Global Journal of Management and Business Studies; Vol. 3 (3), pp. 309-318.

Silva, S. (2016). What is Leadership? Journal of Business Studies Quarterly 2016, Volume 8, Number 1, pp. 1-5. Group Inc

Sinek, S. (2009). Start with why: how great leaders inspire everyone to take action. New York: Penguin

Spicker, P. (2012). "Leadership": A perniciously vague concept. International Journal of Public Sector Management, 2012, 25(1), pp. 34-47.

Surji K. M. (2015). Understanding leadership and factors that Influence leaders' effectiveness. European Journal of Business and Management, Vol.7, No.33, 2015; pp. 154-167.

Ulrich, D. \& Smallwood, N. (c.2012). What is leadership? Michigan Ross School of Business: RBL Group.

Vroom, V. H. and Jago, A. G. (2007). The Role of the Situation in Leadership. American Psychologist, Vol. 62, No. 1, pp. 17-24

Waite, D. and Bogotch, I. (2017). The Wiley international handbook of educational leadership. Hoboken, NJ: John Wiley \& Sons, Inc

Walters, D. C. (2009). Exploring a definition of leadership and the biography of Dr. Frank B. Wynn. Graduate Student Theses, Dissertations, \& Professional Papers. https://scholarworks.umt.edu/etd/1299

Washbush, J. B. (2005). There is no such thing as leadership, revisited. Management Decision, Vol. 43 No. 7/8, 2005; pp. 1078-1085.

Winston, B. E. \& Patterson, K. (2006). An Integrative Definition of Leadership. International Journal of Leadership Studies, Vol. 1 Iss. 2; pp. 6-66.

Yukl, G. (2002). Leadership in Organizations $\left(5^{\text {th }}\right.$ Ed.). Upper Saddle River, NJ: Prentice Hall.

Yukl, G. (2006). Leadership in organizations ( $6^{\text {th }}$ Ed.). Upper Saddle River, NJ: Pearson-Prentice Hall. 